\title{
On the Aetiology of Bovine Farcy in the Sudan
}

\author{
By S. M. EL SANOUSI ${ }^{*}$ AND M. H. TAG EL DIN ${ }^{2}$ \\ ${ }^{1}$ Department of Microbiology and Parasitology, Faculty of Veterinary Science, \\ University of Khartoum, Khartoum, Sudan \\ ${ }^{2}$ Department of Pathology and Diagnosis, Veterinary Research Laboratory, Soba, \\ Khartoum, Sudan
}

(Received 5 August 1985; revised 20 December 1985)

Fifteen strains of the agent of bovine farcy were isolated from lymph nodes of affected cattle. Quantitative analyses of mycolic acids revealed values that allowed the assignment of these strains to the genus Mycobacterium. The organisms bore a greater resemblance to Mycobacterium farcinogenes than to Mycobacterium senegalense.

\section{INTRODUCTION}

Since 1970 it has been known both in Chad and in Senegal that farcy, the disease of African cattle, is really a mycobacteriosis and that in most cases it is not due to Nocardia farcinica as had been believed previously (Chamoiseau, 1979). Chamoiseau (1973) introduced the species Mycobacterium farcinogenes for the agent of bovine farcy and recognized two subspecies, tchadense and senegalense. The former contained the slow-growers with less activity when grown on amides and lower pathogenicity for guinea pigs than the latter. Later, these were raised to species status as $M$. farcinogenes and $M$. senegalense (Chamoiseau, 1979). There is evidence, however, that strains of these mycobacterial species have frequently been mis-identified as $N$. farcinica (Ridell \& Goodfellow, 1983; Ridell et al., 1982, 1985) and reliable methods are needed to distinguish $M$. farcinogenes from $N$. farcinica.

Lipid analyses have provided good characters for the classification and identification of many actinomycete genera (Minnikin et al., 1985). Mycolic acids, which are 2-alkyl, 3-hydroxy longchain fatty acids, have particular importance in the classification of actinomycetes with a wall chemotype IV based on meso-diaminopimelic acid, arabinose and galactose (Lechevalier et al., 1971; Ridell et al., 1982; Minnikin et al., 1985).

The present study describes the development of quantitative analysis of mycolic acids in field strains of bovine farcy in the Sudan as a method for deciding whether these strains belong to the genus Mycobacterium.

\section{METHODS}

Strains. Fifteen strains were isolated from lymph nodes of cattle affected with farcy as previously described (El Sanousi et al., 1977, 1979). The strains isolated from Nayala, Southern Darfur province, Western Sudan, were designated NF3, NF6, NF10, NF11, NF12 and NF13 and those isolated from Kadogli, Southern Kordofan Province, Western Sudan, were designated KF14, KF15, KF16 and KF17. Strains KHF1, KHF2, KHF3, KHF4 and KHF5 were isolated from three abattoirs in Khartoum, Khartoum Province, Central Sudan. Nocardia asteroides, Nocardia brasiliensis and Mycobacterium phlei were obtained from the Central Medical Laboratory of Khartoum. All cultures were grown in modified Sauton's medium at $37^{\circ} \mathrm{C}$ as described by Mordarska et al. (1972).

Mycolic acid extraction. Mycolic acids were extracted from $2 \mathrm{~g}$ wet weight of bacteria by the method of Kanetsuna \& Bartoli (1972), weighed and their melting points determined. The residues collected from all the Mycobacterium strains used in this study were pooled and redissolved in $15.6 \mathrm{ml}$ diethyl ether and $131.2-\mathrm{ml}$ samples were taken. Each sample received one of the following amounts of ethanol: $0.5,0.75,1 \cdot 0,1.25,1.5,1.75$, $2 \cdot 0,2 \cdot 25,2 \cdot 5,2 \cdot 75,3 \cdot 0,3 \cdot 25$ or $3.5 \mathrm{ml}$. The mixtures were stored at $0^{\circ} \mathrm{C}$ for $18 \mathrm{~h}$, centrifuged and the residues 
weighed. The relation between the amount of ethanol used and the mycolic acid extracted was examined by the quadratic equation $\left(Y=a+b x+c x^{2}\right)$ according to the method described by Snedecor \& Cochran (1967).

\section{RESULTS AND DISCUSSION}

The mean value of three trials for the amount of mycolic acid extracted from each strain is shown in Table 1. The effect of increasing the amount of ethanol on mycolic acid extraction is shown in Fig. 1.

A maximum extraction of mycolic acid was obtained when about $2 \mathrm{ml}$ ethanol was added and, thereafter, a negative effect on the amount of mycolic acid was observed with increasing amounts of ethanol. All the test strains from cases of bovine farcy gave amounts of mycolic acid greater than $8 \mathrm{mg}$ per $\mathrm{g}$ of bacteria while the Nocardia strains tested gave amounts of residues less than $2 \mathrm{mg} \mathrm{g}^{-1}$. Only $5 \mathrm{mg}$ (g wet wt bacteria) ${ }^{-1}$ is required for assignment to the genus Mycobacterium (Kanetsuna \& Bartoli, 1972). The melting point of the mycolic acids extracted ranged between 50 and $52{ }^{\circ} \mathrm{C}$ compared to $150{ }^{\circ} \mathrm{C}$ for the residues isolated from Nocardia (Table 1).

The modification of the method of Kanetsuna \& Bartoli (1972) applied in this study for extraction and quantification of mycolic acid is simple and reproducible especially for diagnostic laboratories. The procedure provides a convenient way of distinguishing between mycobacteria of veterinary importance and nocardiae.

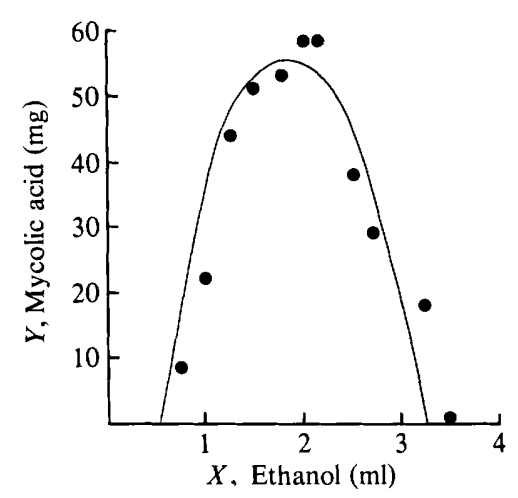

Fig. 1. Mycolic acids extracted with different amounts of ethanol. The relationship is governed by the equation $Y=113.88 X-30 \cdot 11 X^{2}-52 \cdot 85$.

Table 1. Amounts of mycolic acids extracted from different strains of $M$. farcinogenes and $N$. asteroides, $N$. brasiliensis and $M$. phlei

The method of Kanetsuna \& Bartoli (1972) was used. Values are the mean of three determinations.

\begin{tabular}{|c|c|c|c|c|c|}
\hline Strain & $\begin{array}{c}\text { Mycolic acid } \\
{\left[\mathrm{mg}(\mathrm{g} \text { wet } \mathrm{wt})^{-1}\right]}\end{array}$ & $\begin{array}{l}\text { Melting } \\
\text { point } \\
\left({ }^{\circ} \mathrm{C}\right)\end{array}$ & Strain & $\begin{array}{c}\text { Mycolic acid } \\
{\left[\mathrm{mg}(\mathrm{g} \text { wet } \mathrm{wt})^{-1}\right]}\end{array}$ & $\begin{array}{c}\text { Melting } \\
\text { point } \\
\left({ }^{\circ} \mathrm{C}\right)\end{array}$ \\
\hline M. farcinogenes & & & M. farcinogenes & & \\
\hline NF3 & $14 \cdot 66$ & 50 & KHFl & $13 \cdot 41$ & 51 \\
\hline NF6 & $14 \cdot 24$ & 50 & KHF2 & $12 \cdot 60$ & 50 \\
\hline NF10 & $14 \cdot 16$ & 50 & KHF3 & 9.87 & 52 \\
\hline NF 11 & $13 \cdot 43$ & 50 & KHF4 & $12 \cdot 36$ & 51 \\
\hline NF12 & $14 \cdot 62$ & 50 & KHF5 & $12 \cdot 79$ & 51 \\
\hline NF13 & $13 \cdot 56$ & 51 & $N$. asteroides & 0.77 & 150 \\
\hline KF14 & $\begin{array}{l}14 \cdot 16 \\
14 \cdot 21\end{array}$ & $\begin{array}{l}50 \\
50\end{array}$ & N. brasiliensis & $1 \cdot 88$ & 150 \\
\hline $\begin{array}{l}\text { KF15 } \\
\text { KF16 }\end{array}$ & $\begin{array}{r}14.21 \\
8.47\end{array}$ & $\begin{array}{l}50 \\
52\end{array}$ & $M$. phlei & $9 \cdot 22$ & 50 \\
\hline KF17 & $12 \cdot 35$ & 52 & & & \\
\hline
\end{tabular}


Most of the strains tested were also studied by Shigidi et al. (1980) who suggested their placement in the genus Nocardia, However, mycobacteria and nocardiae share many antigens in common, and the presence or absence of a single unidentified precipitinogen can not be used to distinguish between the two genera (Ridell, 1983). Moreover, Ridell et al. (1985), using the same strains but designated GB 375-GB 385, concluded that $M$. farcinogenes and $M$. senegalense, but not $N$. farcinica, are the principal agents of bovine farcy in the Sudan, thus substantiating the findings of El Sanousi et al. (1977) and El Sanousi \& Salih (1979). Since all the Sudanese strains of bovine farcy tested were of the slow-growing type and since they are highly pathogenic for guinea pigs with weak activity when grown on amide, they bear a greater resemblance to $M$. farcinogenes than to $M$. senegalense. It is also apparent that $N$. farcinica is not commonly encountered as a cause of bovine farcy in Eastern Africa.

We should like to acknowledge the excellent technical assistance of Mr R. Godart, ODA, British Embassy, Khartoum. Thanks are extended to $\operatorname{Dr} \mathrm{O}$. A. El Khidir for the statistical analysis.

\section{REFERENCES}

Chamoiseau, G. (1973). Mycobacterium farcinogenes agent causal du farcin du boeuf en Afrique. Annales de microbiologie (Institut Pasteur) 124A, 215-222.

Chamoiseau, G. (1979). Etiology of farcy in African bovines: nomenclature of the causal organisms $M y c o b a c t e r i u m$ farcinogenes (Chamoiseau) and $M y$ cobacterium senegalense (Chamoiseau) comb. nov. International Journal of Systematic Bacteriology 29, $407-410$

El Sanousi, S. M. \& Salih, M. A. M. (1979). Miliary bovine farcy experimentally induced in a calf. Veterinary Pathology 16, 372-373.

El Sanousi, S. M., Tag El Din, M. H. \& Abdel WAHAB, S. M. (1977). Classification of the bovine farcy organism. Tropical Animal Health and Production $9,124$.

El Sanousi, S. M., Salih, M. A. M., Mousa, M. T., TAG El DIN, M. H. \& ALI, A. M. (1979). Further studies on the properties of the aetiology of bovine farcy isolated from Sudanese cattle. Revue d'élevage et de médecine vétérinaire des pays tropicaux 32, 135141 .

Kanetsuna, F. \& Bartoli, A. (1972). A simple chemical method to differentiate Mycobacterium from Nocardia. Journal of General Microbiology 70, 209-212.

Lechevalier, M. P., Horan, A. C. \& Lechevalier, H. (1971). Lipid composition in the classification of nocardiae and mycobacteria. Journal of Bacteriology 105, 313-318.

Minnikin, D. E., Minnikin, S. M., Parlett, J. H. \& GoODFELlow, M. (1985). Mycolic acids pattern of some rapidly-growing species of Mycobacterium.
Zentralblatt für Bakteriologie, Mikrobiologie und Hygiene A259, 446-460.

MoRdarsKa, H., MoRdarSKi, M. \& GoOdFellow, M. (1972). Chemotaxonomic characters and classification of some nocardioform bacteria. Journal of General Microbiology 71, 77-86.

RiDELL, M. (1983). Immunodiffusion analyses of Mycobacterium farcinogenes, Mycobacterium senegalense and some other mycobacteria. Journal of General Microbiology 129, 613-619.

Ridell, M. \& GoOdFEllow, M. (1983). Numerical classification of Mycobacterium farcinogenes, Mycobacterium senegalense and related taxa. Journal of General Microbiology 129, 599-611.

Ridell, M., Goodfellow, M., Minnikin, D. E., Minnikin, S. M. \& Hutchinson, I. G. (1982). Classification of Mycobacterium farcinogenes and Mycobacterium senegalense by immunodiffusion and thin-layer chromatography of long-chain components. Journal of General Microbiology 128, 12991307.

Ridell, M., Goodfellow, G. \& ABdulle, A. B. (1985). Identification of actinomycetes isolated from cases of bovine farcy in the Sudan. Zentralblatt für Bakteriologie, Mikrobiologie und Hygiene A259, 4350.

Shigidi, M. T. A., Mirghani, T. \& Musa, M. T. (1980). Characterisation of Nocardia farcinica isolated from cattle with bovine farcy. Research in Veterinary Science 28, 207-211.

SNedecor, G. W. \& Cochran, W. G. (1980). Statistical Methods, 7 th edn, p. 398. Ames, Iowa: Iowa State University Press. 